Article

\title{
Incorporating the Thiazolo[5,4-d]thiazole Unit into a Coordination Polymer with Interdigitated Structure
}

\author{
Simon Millan, Gamall Makhloufi and Christoph Janiak * \\ Institut für Anorganische Chemie und Strukturchemie, Heinrich-Heine-Universität, Universitätsstraße 1, \\ 40225 Düsseldorf, Germany; simon.millan@hhu.de (S.M.); gamall.makhloufi@hhu.de (G.M.) \\ * Correspondence: janiak@hhu.de; Tel.: +49-211-81-12286
}

Received: 21 December 2017; Accepted: 6 January 2018; Published: 12 January 2018

\begin{abstract}
The linker 2,5-di(4-pyridyl)thiazolo[5,4-d]thiazole (Dptztz), whose synthesis and structure is described here, was utilized together with benzene-1,3-dicarboxylate (isophthalate, 1,3-BDC ${ }^{2-}$ ) for the preparation of the two-dimensional coordination network [ $\mathrm{Zn}(1,3-\mathrm{BDC}) \mathrm{Dptztz}] \cdot \mathrm{DMF}$ $(\mathrm{DMF}=$ dimethylformamide $)$ via a solvothermal reaction. Compound [Zn(1,3-BDC)Dptztz].DMF belongs to the class of coordination polymers with interdigitated structure (CIDs). The incorporated DMF solvent molecules can be removed through solvent exchange and evacuation such that the supramolecular 3D packing of the 2D networks retains porosity for $\mathrm{CO}_{2}$ adsorption in activated [Zn(1,3-BDC)Dptztz]. The first sorption study of a tztz-functionalized porous metal-organic framework material yields a BET surface of $417 \mathrm{~m}^{2} / \mathrm{g}$ calculated from the $\mathrm{CO}_{2}$ adsorption data. The heat of adsorption for $\mathrm{CO}_{2}$ exhibits a relative maximum with $27.7 \mathrm{~kJ} / \mathrm{mol}$ at an adsorbed $\mathrm{CO}_{2}$ amount of about $4 \mathrm{~cm}^{3} / \mathrm{g}$ STP, which is interpreted as a gate-opening effect.
\end{abstract}

Keywords: coordination polymer; MOF; gate-opening; thiazolo[5,4-d]thiazole; mixed-ligand

\section{Introduction}

Metal-organic frameworks are an intensively studied class of porous materials. Due to the immense quantity of possible inorganic and organic building units several applications are discussed (e.g., gas storage and separation, catalysis, sensing and heat transformation) [1-13]. Many different organic functionalities have been introduced into the frameworks either by a priori ligand functionalization or by post synthetic modification [14-16]. 4,4'-Biypridine based ligands have been used to construct a diverse set of different topologies (e.g., one-dimensional chains, ladders, two-dimensional and three-dimensional networks) [17]. 4,4'-Bipyridine ligands are also widely used in the synthesis of open network structures in combination with dicarboxylate ligands (e.g., terephthalate, isophthalate) via the so called mixed-ligand strategy $[18,19]$. Through functionalization of the organic ligands, the pore surface of those mixed-ligand MOFs can be tuned to enhance the selectivity in their sorption or sensing properties [20-23]. One famous family of mixed-ligands MOFs are the CIDs (coordination polymers with interdigitated structure) popularized by Kitagawa and co-workers. CIDs consist of an angular ligand (e.g., isophthalate, benzophenone-4, $4^{\prime}$-dicarboxylate, azulene-1,6-dicarboxylate) and a 4,4'-bipyridine derivative and divalent transition metal ions. CIDs show very intriguing sorption properties due to their potential for functionalization and often inherent structural flexibility [24-29].

The heterocyclic thiazolo[5,4-d]thiazole (tztz) system (Figure 1) experienced a renaissance in the last decade after it was first prepared by Ketcham et al. in the 1960s [30]. The tztz unit was incorporated into photoactive materials due to its rigid and planar structure and electron deficiency. Both Maes et al. and Dessi et al. reviewed the synthetic procedures to obtain tztz-containing small molecules and polymers as well as their application in the field of organic 
electronics (e.g., OFETs, OSCs) [31,32]. In contrast, the tztz unit has been reported only in relatively few coordination compounds ( 15 hits in the CCDC database). The first examples were ruthenium and copper complexes with the doubly chelating 2,5-di(2-pyridyl)thiazolo[5,4-d]thiazole synthesized by Steel et al. [33]. Coordination polymers with 2,5-thiazolo[5,4-d]thiazoledicarboxylic acid (Figure 1) were obtained by Cheetham et al. with alkaline earth metals, whose connectivities vary with the cation size, and by Palmisano et al. with some transition metals, in which the ligand shows a $\mathrm{N}, \mathrm{O}$-chelating mode $[34,35]$. D'Alessandro et al. incorporated the donor-acceptor ligand $N, N^{\prime}$-(thiazolo[5,4-d]thiazole-2,5-diylbis(4,1-phenylene))bis( $N$-(pyridine-4-yl)pyridin-4-amine into a two-dimensional zinc MOF and studied its electrochemical properties [36]. Recently the same group published the spectroelectrochemical properties of a ruthenium coordination complex with this ligand [37]. Additionally, Dai et al. synthesized tztz-linked microporous organic polymers, which show a high $\mathrm{CO}_{2}: \mathrm{N}_{2}$ selectivity [38].

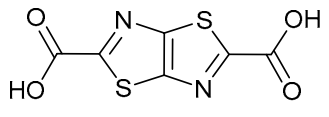

2,5-thiazolo[5,4-d]thiazoledicarboxylic acid

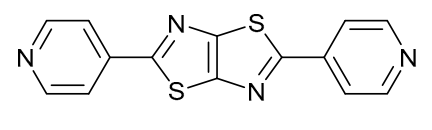
2,5-di(4-pyridyl)thiazolo[5,4-d]thiazole
(Dptztz)

Figure 1. Examples of tztz-containing ligands.

Herein, we present the synthesis, structural analysis and the sorption properties of a new coordination polymer with interdigitated structure of the formula [Zn(1,3-BDC)Dptztz] consisting of $\mathrm{Zn}^{2+}$ ions, isophthalate and the 4,4'-bipyridine derivative 2,5-di(4-pyridyl)thiazolo[5,4-d]thiazole (Dptztz) (Figure 1, Scheme 1).

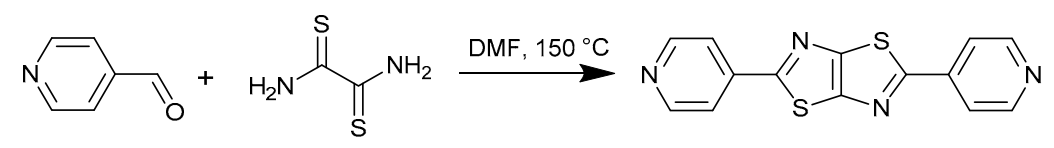

Scheme 1. Reaction scheme for the synthesis of 2,5-di(4-pyridyl)thiazolo[5,4-d]thiazole from 4-pyridinecarboxaldehyde and dithioaxamide.

\section{Materials and Methods}

The chemicals used were obtained from commercial sources. No further purification has been carried out. CHN analysis was performed with a Perkin Elmer CHN 2400 (Perkin Elmer, Waltham, MA, USA). IR-spectra were recorded on a Bruker Tensor 37 IR spectrometer (Bruker Optics, Ettlingen, Germany) with ATR unit. Thermogravimetric analysis (TGA) was done with a Netzsch TG 209 F3 Tarsus (Netzsch, Selb, Germany) in the range from 20 to $700{ }^{\circ} \mathrm{C}$, equipped with Al-crucible and applying a heating rate of $10 \mathrm{~K} \cdot \mathrm{min}^{-1}$ under nitrogen. The melting point was determined using a Büchi Melting Point apparatus B540. The powder X-ray diffraction pattern (PXRD) was obtained on a Bruker D2 Phaser powder diffractometer with a flat silicon, low background sample holder, at $30 \mathrm{kV}$, $10 \mathrm{~mA}$ for $\mathrm{Cu}-\mathrm{K} \alpha$ radiation $(\lambda=1.5418 \AA)$. Sorption isotherms were measured using a Micromeritics ASAP 2020 automatic gas sorption analyzer equipped with oil-free vacuum pumps (ultimate vacuum $<10^{-8}$ mbar) and valves, which guaranteed contamination free measurements. The sample was connected to the preparation port of the sorption analyzer and degassed under vacuum until the outgassing rate, i.e., the rate of pressure rise in the temporarily closed manifold with the connected sample tube, was less than $2 \mu$ Torr $/ \mathrm{min}$ at the specified temperature of $120^{\circ} \mathrm{C}$. After weighing, the sample tube was then transferred to the analysis port of the sorption analyzer. All used gases $\left(\mathrm{He}, \mathrm{N}_{2}\right.$, $\mathrm{CO}_{2}$ ) were of ultra-high purity (UHP, grade 5.0, 99.999\%) and the STP volumes are given according to the NIST standards $(293.15 \mathrm{~K}, 101.325 \mathrm{kPa})$. Helium gas was used for the determination of the cold and warm free space of the sample tubes. The heat of adsorption values were calculated using the ASAP 
2020 v3.05 software. Water sorption isotherms were obtained volumetrically from a Quantachrome Autosorb iQ MP instrument equipped with an all-gas option. Prior to the sorption experiments, the compounds were degassed under dynamic vacuum.

2,5-Di(4-pyridyl)thiazolo[5,4-d]thiazole (Dptztz): $1.02 \mathrm{~g}(8.5 \mathrm{mmol})$ dithiooxamide and $2.0 \mathrm{~mL}$ (22 mmol, 2.6 eq) 4-pyridinecarboxaldehyde in $50 \mathrm{~mL}$ anhydrous DMF were refluxed for $6.5 \mathrm{~h}$ under nitrogen. During cooling the reaction mixture to room temperature, the product crystallized out in form of yellow prisms. The ligand was filtered and washed with a small amount of DMF and extensively with water. After drying in a vacuum oven at $60^{\circ} \mathrm{C}$ overnight $1.82 \mathrm{~g}(6.1 \mathrm{mmol}, 72 \%)$ were obtained. ${ }^{1} \mathrm{H}-\mathrm{NMR}\left(300 \mathrm{MHz}, \mathrm{DMSO}_{6}\right) \delta[\mathrm{ppm}]: 8.78\left({ }^{d},{ }^{4} J_{H, H}=6.12 \mathrm{~Hz}, 2 \mathrm{H}\right), 7.88\left(d,{ }^{4} J_{H, H}=6.12 \mathrm{~Hz}\right.$, 2H); MS (EI) m/z [rel. int.]: 296 (100\%); 87.9 (91\%); mp 319-322 ${ }^{\circ} \mathrm{C}$.

[Zn(1,3-BDC)Dptztz]: $5.0 \mathrm{mg}(0.017 \mathrm{mmol})$ of Dptztz were dissolved in $3 \mathrm{~mL}$ of hot DMF in a Pyrex tube. $5.4 \mathrm{mg}(0.020 \mathrm{mmol})$ of $\mathrm{Zn}\left(\mathrm{NO}_{3}\right)_{2} \cdot 4 \mathrm{H}_{2} \mathrm{O}$ and $2.8 \mathrm{mg}(0.020 \mathrm{mmol})$ of isophthalic acid dissolved in $2 \mathrm{~mL}$ of DMF were added to the warm solution. The Pyrex tube was capped and placed into a preheated isothermal oven at $80^{\circ} \mathrm{C}$. After $12 \mathrm{~h}$ the first crystals appeared. After 3 days, the sample was removed from the oven and the solvent was directly exchanged with $3 \times 3 \mathrm{~mL}$ of hot DMF. A light yellow crystal was selected to collect the single crystal data. Yield: $4 \mathrm{mg}$.

A larger amount of material was prepared by dissolving $100.4 \mathrm{mg}(0.34 \mathrm{mmol})$ of Dptztz in $40 \mathrm{~mL}$ of hot DMF in a $100 \mathrm{~mL}$ Schott vial. Afterwards $88.4 \mathrm{mg}(0.34 \mathrm{mmol})$ of $\mathrm{Zn}\left(\mathrm{NO}_{3}\right) \cdot 4 \mathrm{H}_{2} \mathrm{O}$ and $56.6 \mathrm{mg}(0.34 \mathrm{mmol})$ of isophthalic acid dissolved in $10 \mathrm{~mL}$ of DMF were added and placed in an isothermal oven preheated at $120^{\circ} \mathrm{C}$. The sample was taken out after 3 days and the solvent was directly exchanged with $3 \times 20 \mathrm{~mL}$ of hot DMF. Yield: $182.6 \mathrm{mg}(90 \%)$. EA [\%] calc. for: $\mathrm{C}_{22} \mathrm{H}_{12} \mathrm{~N}_{4} \mathrm{O}_{4} \mathrm{~S}_{2} \mathrm{Zn} \mathrm{C}$ 50.25, H 2.30 N 10.70; found: C 50.89, H 2.93, N 11.51. IR (ATR) $\tilde{\mathrm{v}}_{\max }\left[\mathrm{cm}^{-1}\right]: 3433,1608,1564,1443$, $1391,1213,1014,833,743,724,662,619,510$.

\section{Single Crystal X-ray Structures}

Suitable crystals were carefully selected under a polarizing microscope, covered in protective oil and mounted on a $0.05 \mathrm{~mm}$ cryo loop. Data collection: Bruker Kappa APEX2 CCD X-ray diffractometer (Bruker AXS Inc., Madison, WI, USA) with microfocus tube, Mo-K $\alpha$ radiation $(\lambda=0.71073 \AA)$, multi-layer mirror system, $\omega$-scans; data collection with APEX2 [39], cell refinement with SMART and data reduction with SAINT [39], experimental absorption correction with SADABS [40]. Structure analysis and refinement: All structures were solved by direct methods using SHELXL2014 [41,42]; refinement was done by full-matrix least squares on $F^{2}$ using the SHELX-97 program suite. The hydrogen atoms for aromatic $\mathrm{CH}$ and for the amide group in DMF were positioned geometrically $\left(\mathrm{C}-\mathrm{H}=0.95 \AA\right.$ ) and refined using a riding model (AFIX 43) with $\mathrm{U}_{\text {iso }}(\mathrm{H})=1.2 \mathrm{U}_{\text {eq }}(\mathrm{C})$. The hydrogen atoms for $\mathrm{CH}_{3}$ of DMF were positioned geometrically $(\mathrm{C}-\mathrm{H}=0.98 \AA$ ) and refined using a riding model (AFIX 137) with $\mathrm{U}_{\text {iso }}(\mathrm{H})=1.5 \mathrm{U}_{\text {eq }}(\mathrm{C})$. In [ $\mathrm{Zn}(1,3-\mathrm{BDC})$ Dptztz] the thiazolothiazol (tztz) moiety was refined with a disorder model corresponding to a ring flip, which exchanges the $\mathrm{S}$ and $\mathrm{N}$ orientation, using PART $n$ commands. The occupation factors of the $\mathrm{S}$ and $\mathrm{N}$ atoms were refined to about 0.904 for the A atoms and 0.096 for the B atoms. Thus, the disorder is relatively minor with only about $9.6 \%$ of the $\mathrm{S}$ and $\mathrm{N}$ atoms in the flipped position. The major atom tztz positions are designated as " $\mathrm{A}$ ", the minor ones as " $\mathrm{B}$ ". The minor positions could only be refined isotropically. The DMF crystal solvent molecule contained disorder in the two methyl groups, with two positions for each methyl group. This disorder does not give a perfect oriented $\mathrm{Me}_{2} \mathrm{~N}$ group but we decided to keep the slightly disordered DMF molecule instead of removing its contribution with SQUEEZE. Each methyl group disorder was refined independently concerning the occupation factors. Crystal data and details on the structure refinement are given in Table 1. Graphics were drawn with DIAMOND [43]. Analyses on the supramolecular interaction were done with PLATON [44]. Phase purity and the representative nature of the single crystal was verified by positively matching the simulated and experimental powder X-ray diffractogram (PXRD) of the as-synthesized sample (Figure 2). CCDC 1812892 and 1812893 contain 
the supplementary crystallographic data for this paper. These data can be obtained free of charge via http:/ / www.ccdc.cam.ac.uk/conts/retrieving.html.

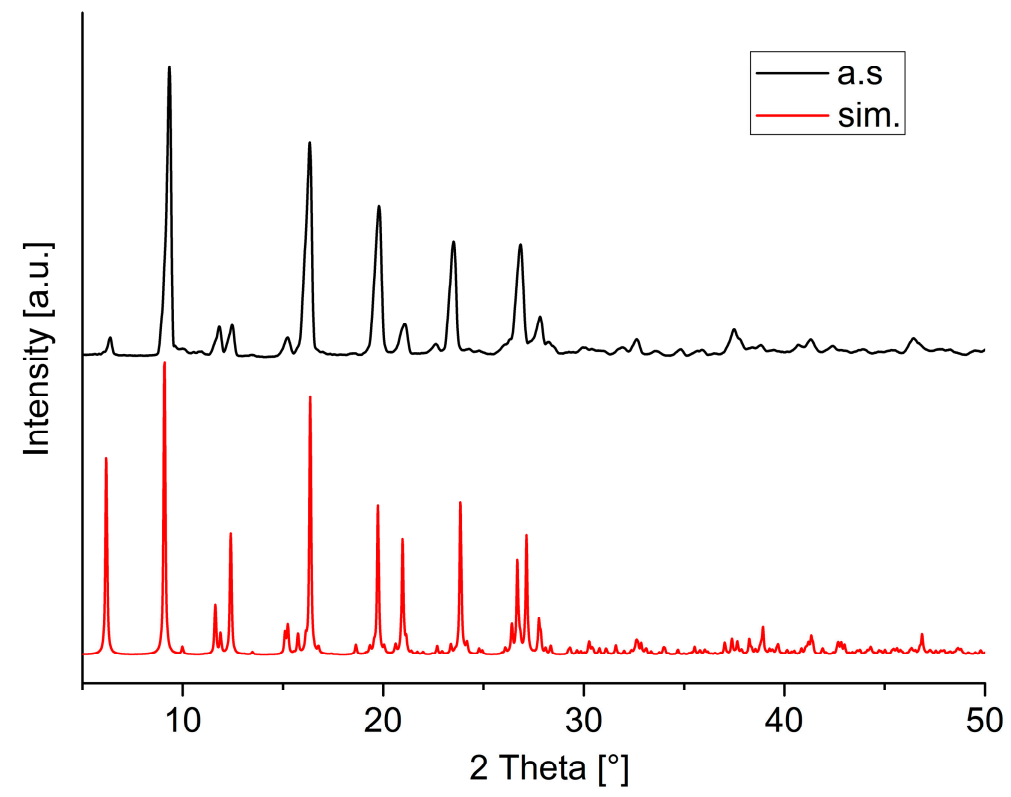

Figure 2. PXRD pattern of [Zn(1,3-BDC)Dptztz]·DMF (simulated (red), as-synthesized (black)).

Table 1. Crystal data and refinement details.

\begin{tabular}{|c|c|c|}
\hline & Dptztz & [Zn(1,3 BDC)Dptztz]·DMF \\
\hline Chemical formula & $\mathrm{C}_{14} \mathrm{H}_{8} \mathrm{~N}_{4} \mathrm{~S}_{2}$ & $\mathrm{C}_{22} \mathrm{H}_{12} \mathrm{~N}_{4} \mathrm{O}_{4} \mathrm{~S}_{2} \mathrm{Zn} \cdot \mathrm{C}_{3} \mathrm{H}_{7} \mathrm{NO}$ \\
\hline $\mathrm{Mr}$ & 296.36 & 598.94 \\
\hline Crystal system, space group & Monoclinic, $\mathrm{P} 2_{1} / \mathrm{c}$ & Triclinic, P $\overline{1}$ \\
\hline Temperature (K) & 100 & 100 \\
\hline $\mathrm{a}(\AA)$ & $8.3873(5)$ & $9.1388(6)$ \\
\hline $\mathrm{b}(\AA)$ & $6.3140(3)$ & $10.0354(7)$ \\
\hline c $(\AA)$ & $11.7170(6)$ & $14.2804(11)$ \\
\hline$\alpha\left({ }^{\circ}\right)$ & 90 & $88.417(4)$ \\
\hline$\beta\left(^{\circ}\right)$ & $93.699(3)$ & $88.236(5)$ \\
\hline$\gamma\left({ }^{\circ}\right)$ & 90 & $75.636(4)$ \\
\hline $\mathrm{V}\left(\AA^{3}\right)$ & $619.21(6)$ & $1267.86(16)$ \\
\hline Z & 2 & 2 \\
\hline$\mu\left(\mathrm{mm}^{-1}\right)$ & 0.423 & 1.181 \\
\hline Crystal size $(\mathrm{mm})$ & $0.10 \times 0.05 \times 0.05$ & $0.10 \times 0.05 \times 0.01$ \\
\hline Absorption correction & $\begin{array}{l}\text { Multi-scan, wR2(int) was } 0.1649 \text { before and } \\
0.0771 \text { after correction. The Ratio of minimum to } \\
\text { maximum transmission is } 0.8473 \text {. The } \lambda / 2 \\
\text { correction factor is } 0.0015 \text {. }\end{array}$ & $\begin{array}{l}\text { Multi-scan, wR2(int) was } 0.1533 \text { before } \\
\text { and } 0.0488 \text { after correction. The Ratio of } \\
\text { minimum to maximum transmission is } \\
0.9318 \text {. The } \lambda / 2 \text { correction factor is } 0.0015 \text {. }\end{array}$ \\
\hline $\mathrm{T}_{\min }, \mathrm{T}_{\max }$ & $0.6330,0.7471$ & $0.6951,0.7460$ \\
\hline $\begin{array}{l}\text { No. of measured, independent } \\
\text { and observed reflections }\end{array}$ & $6837,965,847[\mathrm{I}>2 \sigma(\mathrm{I})]$ & $17151,4743,3696[\mathrm{I}>2 \sigma(\mathrm{I})]$ \\
\hline $\mathrm{R}_{\text {int }}$ & 0.049 & 0.045 \\
\hline$(\sin \theta / \lambda) \max \left(\AA^{-1}\right)$ & 0.639 & 0.612 \\
\hline $\begin{array}{c}\mathrm{R}, \mathrm{wR}\left(F^{2}\right), S\left[F^{2}>2 \sigma\left(F^{2}\right)\right] \\
\mathrm{R}, \mathrm{wR}\left(F^{2}\right), S \text { [all data] }\end{array}$ & $\begin{array}{c}0.0284,0.0675,1.067 \\
0.359,0.0699,1.067\end{array}$ & $\begin{array}{l}0.0400,0.0849,1.055 \\
0.0609,0.0916,1.055\end{array}$ \\
\hline No. of reflections & 965 & 4743 \\
\hline No. of parameters & 91 & 364 \\
\hline$\Delta \varrho_{\max }, \Delta \varrho_{\min }\left(\mathrm{e} \cdot \AA^{-3}\right)$ & $0.238,-0.182$ & $0.645,-0.581$ \\
\hline
\end{tabular}




\section{Results and Discussion}

2,5-Di(4-pyridyl)thiazolo[5,4-d]thiazole (Dptztz) was synthesized according to the literature by the condensation of 4-pyridinecarboxaldehyde and dithioaxamide (Scheme 1) [45,46].

Single crystals of Dptztz were obtained after recrystallization from DMF in form of yellow prisms. Dptztz crystallizes in the monoclinic space group $\mathrm{P} 2_{1} / \mathrm{c}$ with half of the molecule in the asymmetric unit as the molecule sits on an inversion center (Figure 3). The molecule is almost planar with a dihedral angle between the pyridine ring and the tztz moiety of $13.65^{\circ}$.

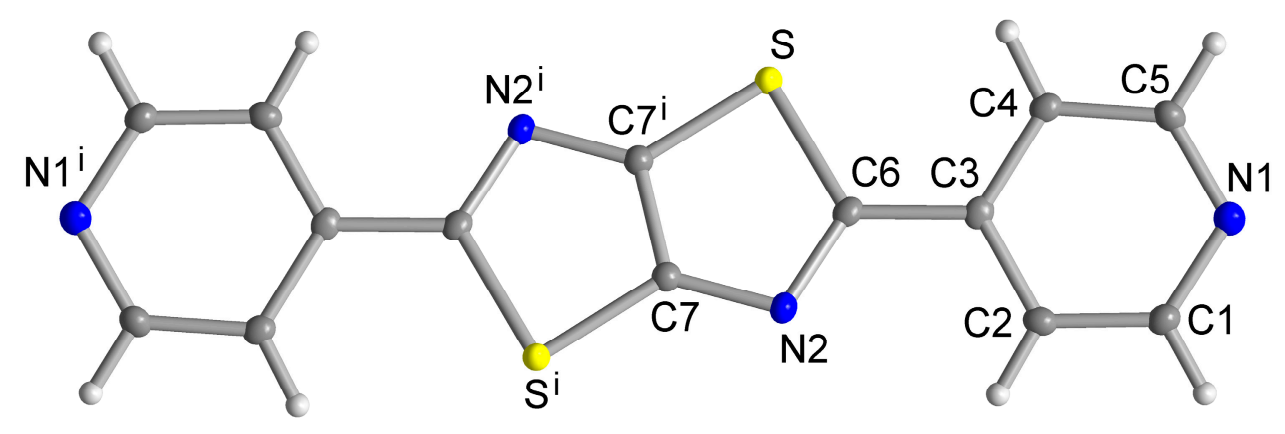

Figure 3. Molecular structure of Dptztz (50\% thermal ellipsoids, symmetry transformation $1-x$, $2-\mathrm{y}, 2-\mathrm{z})$.

Complementary $\mathrm{CH} \cdots \mathrm{N}$ hydrogen bonds between $\mathrm{N} 1$ and $\mathrm{C} 1-\mathrm{H} 1$ of adjacent Dptztz molecules form 1D strands which are parallel displaced by $\pi-\pi$ interactions (Figure S1 in Supplementary Material).

Single crystals of the coordination network [ $\mathrm{Zn}(1,3-\mathrm{BDC})$ Dptztz]. DMF were obtained after three days from a solvothermal reaction of $\mathrm{Zn}\left(\mathrm{NO}_{3}\right)_{2} \cdot 4 \mathrm{H}_{2} \mathrm{O}$, isophthalic acid and Dptztz in a molar ratio 1:1:1 in DMF at $80^{\circ} \mathrm{C}$. Due to the low solubility of Dptztz in common organic solvents, the reaction was carried out in a concentration of $3.4 \times 10^{-3} \mathrm{~mol} / \mathrm{L}$ and the mother liquor was directly exchanged with hot DMF after the crystallization process to remove unreacted Dptztz ligand. A larger amount of material for the sorption experiments was synthesized by scaling up the reaction by the factor of twenty in twice the concentration $\left(6.8 \times 10^{-3} \mathrm{~mol} / \mathrm{L}\right)$ at $120^{\circ} \mathrm{C}$.

The crystal structure of the two-dimensional (2D) coordination network [Zn(1,3-BDC)Dptztz].DMF was determined by single crystal diffraction analysis at $100 \mathrm{~K}$. Compound [Zn(1,3-BDC)Dptztz] crystallizes in the triclinic space group $P-1$. The asymmetric unit consists of one $\mathrm{Zn}(\mathrm{II})$ ion, one molecule of the linkers $1,3-\mathrm{BDC}^{2-}$ and Dptztz, each, and a dimethylformamide (DMF) solvent molecule (Figure 4, Figure S2). One carboxylate group of 1,3-BDC ${ }^{2-}$ connects two symmetry equivalent $\mathrm{Zn}$ (II) ions in a syn-syn-bis-monodentate coordination mode into a dinuclear unit with a $\mathrm{Zn} \cdot \mathrm{Zn}$ distance of $4.082 \AA$. The other carboxylate group chelates an adjacent $\mathrm{Zn}$ atom. Thereby the 1,3-BDC linkers bridge between neighboring dinuclear entities to form a one-dimensional double strand along the $b$-axis (Figure 5a). These double strands are pillared by Dptztz into a 2D coordination network structure (Figure $5 b$ ). The secondary building unit of the structure is the dinuclear unit $\left\{\mathrm{Zn}_{2}\left(\mathrm{O}_{2} \mathrm{C}\right)_{4} \mathrm{~N}_{4}\right\}$. The 2D layers assemble through $\pi-\pi$ interactions between isophthalate aryl rings and $\mathrm{CH}-\pi$ interactions between an isophthalate and a pyridyl-moiety of Dptztz of adjacent layers into a 3D supramolecular network (Figure $5 \mathrm{c}$ and Figure S3, Table S1). The 2D network in [Zn(1,3-BDC)Dptztz] is isotopic to the aforementioned CIDs (coordination polymers with interdigitated structure) studied by Kitagawa and co-workers [24-29]. 


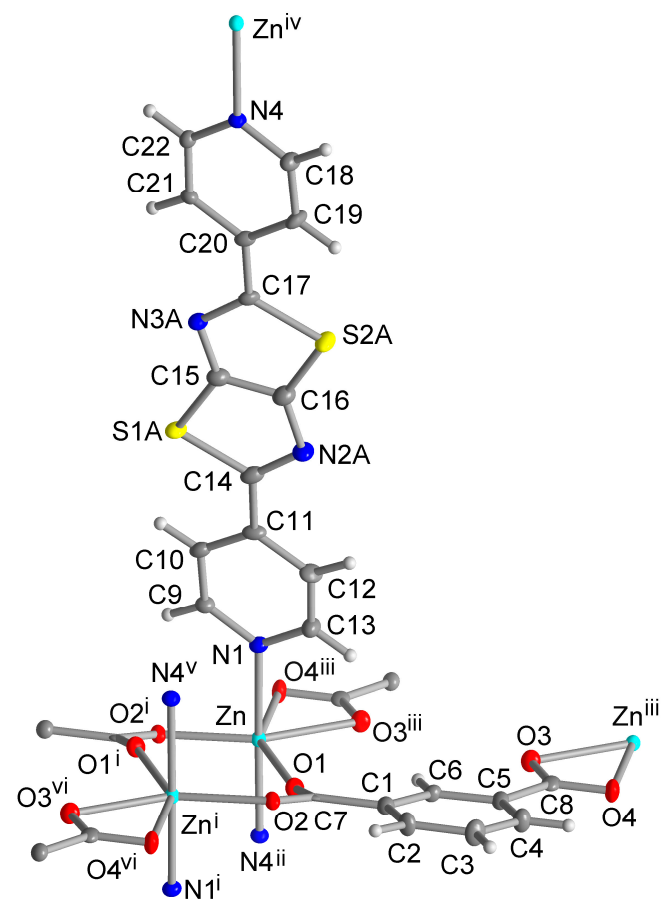

Figure 4. Extended asymmetric unit of [Zn(1,3-BDC)Dptztz].DMF (50\% thermal ellipsoids; symmetry transformations: $\mathrm{i}=-\mathrm{x}+2,-\mathrm{y},-\mathrm{z}+1$; ii $=\mathrm{x}+1, \mathrm{y}, \mathrm{z}+1$; iii $=-\mathrm{x}+2,-\mathrm{y}+1,-\mathrm{z}+1$; iv $=\mathrm{x}-1, \mathrm{y}, \mathrm{z}-1$; $\mathrm{v}=-\mathrm{x}+1,-\mathrm{y},-\mathrm{z}, \mathrm{vi}=\mathrm{x}, \mathrm{y}-1, \mathrm{z})$. For the slight ring-flip disorder of the thiazolothiazol moiety and the DMF solvent molecule, which is omitted here for clarity, see Figure S2 in Supplementary Material. See Table 2 for selected bond lengths and angles.

Table 2. Selected bond lengths and angles $\left(\AA^{\circ},{ }^{\circ}\right)$ in $[\mathrm{Zn}(1,3-\mathrm{BDC}) \mathrm{Dptztz}]$.

\begin{tabular}{|c|c|c|c|}
\hline $\mathrm{Zn}-\mathrm{O} 1$ & $2.0532(18)$ & $\mathrm{Zn}-\mathrm{O} 4^{\mathrm{iii}}$ & 2.2269 (19) \\
\hline $\mathrm{Zn}-\mathrm{O} 2^{\mathrm{i}}$ & $2.0218(18)$ & Zn-N1 & $2.166(3)$ \\
\hline $\mathrm{Zn}-\mathrm{O} 3^{\mathrm{iii}}$ & 2.1569 (19) & $\mathrm{Zn}-\mathrm{N} 4^{\mathrm{ii}}$ & $2.151(3)$ \\
\hline $\mathrm{O} 1-\mathrm{Zn}-\mathrm{O} 2^{\mathrm{i}}$ & $119.30(7)$ & $\mathrm{O} 2^{\mathrm{i}}-\mathrm{Zn}-\mathrm{N} 4^{\mathrm{ii}}$ & $89.34(9)$ \\
\hline $\mathrm{O} 1-\mathrm{Zn}-\mathrm{O} 3^{\mathrm{iii}}$ & $88.78(7)$ & 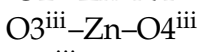 & $60.01(7)$ \\
\hline $\mathrm{O} 1-\mathrm{Zn}-\mathrm{O} 4^{\mathrm{iii}}$ & $148.39(7)$ & $\mathrm{O} 3^{\mathrm{iii}-\mathrm{Zn}-\mathrm{N} 1}$ & $90.18(9)$ \\
\hline O1-Zn-N1 & $89.84(9)$ & 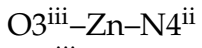 & $90.56(9)$ \\
\hline $\mathrm{O} 1-\mathrm{Zn}-\mathrm{N} 4^{\mathrm{ii}}$ & $86.00(9)$ & $\mathrm{O} 4^{\mathrm{iii}-\mathrm{Zn}-\mathrm{N} 1}$ & $94.77(8)$ \\
\hline $\mathrm{O} 2^{\mathrm{i}}-\mathrm{Zn}-\mathrm{O} 3^{\mathrm{iii}}$ & $151.83(7)$ & 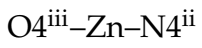 & $89.21(8)$ \\
\hline $\mathrm{O} 2^{\mathrm{i}}-\mathrm{Zn}-\mathrm{O} 4^{\mathrm{iii}}$ & $91.82(7)$ & $\mathrm{N} 1-\mathrm{Zn}-\mathrm{N} 4^{\mathrm{ii}}$ & $175.76(8)$ \\
\hline $\mathrm{O} 2^{\mathrm{i}}-\mathrm{Zn}-\mathrm{N} 1$ & 91.99 (9) & & \\
\hline
\end{tabular}

Symmetry transformations: $\mathrm{i}=-\mathrm{x}+2,-\mathrm{y},-\mathrm{z}+1$; ii $=\mathrm{x}+1, \mathrm{y}, \mathrm{z}+1$; iii $=-\mathrm{x}+2,-\mathrm{y}+1,-\mathrm{z}+1$.

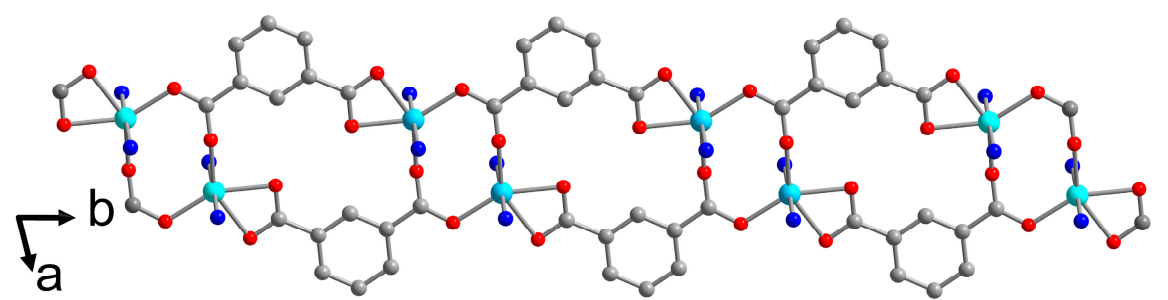

(a)

Figure 5. Cont. 


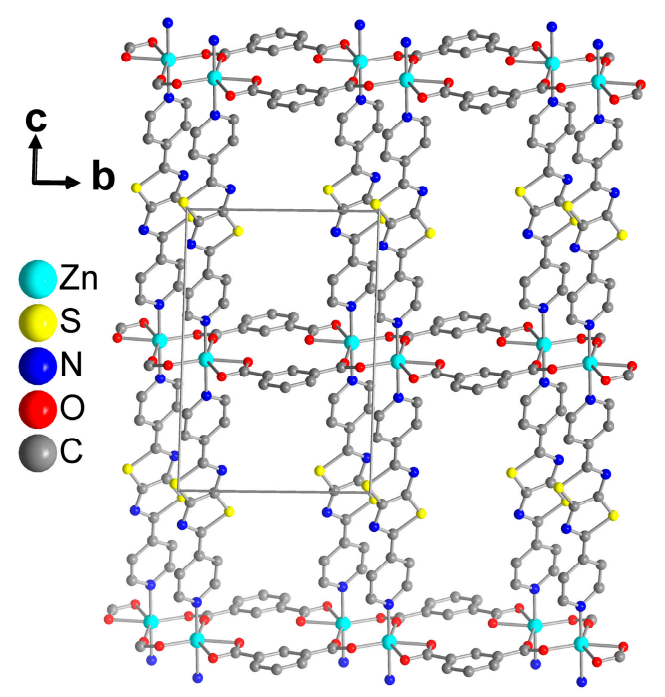

(b)

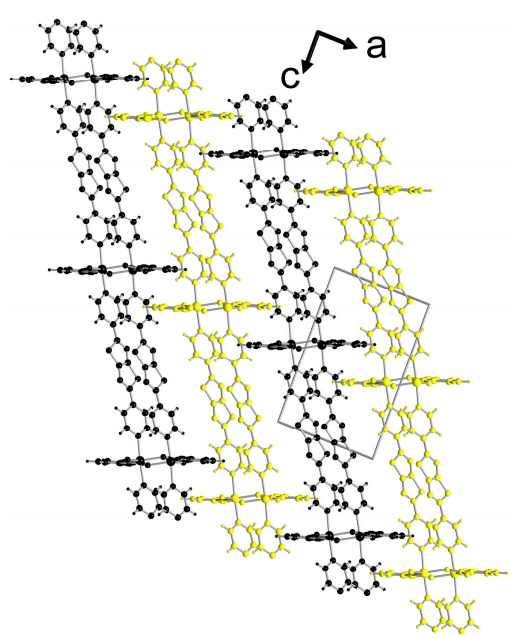

(c)

Figure 5. (a) $1 \mathrm{D}$ double strand of $\mathrm{Zn}^{2+}$ and $1,3-\mathrm{BDC}^{2-}$ along the $b$-axis and (b) $2 \mathrm{D}$ coordination network structure in the $b c$ plane and (c) supramolecular 3D packing of the $2 \mathrm{D}$ layers in [Zn(1,3-BDC)Dptztz].DMF (H atoms in (a,b) and DMF solvent molecules are not shown for clarity). In (c) the 2D layers are colored alternately black and yellow for clarity.

The thermogravimetric analysis in Figure 6 shows a weight loss of $10.6 \%$ between 90 and $200{ }^{\circ} \mathrm{C}$ (calc. $12.2 \%$ for one DMF molecule per formula unit of [Zn(1,3-BDC)Dptztz].DMF). The residual [Zn(1,3-BDC)Dptztz] framework shows stability up to $280^{\circ} \mathrm{C}$.

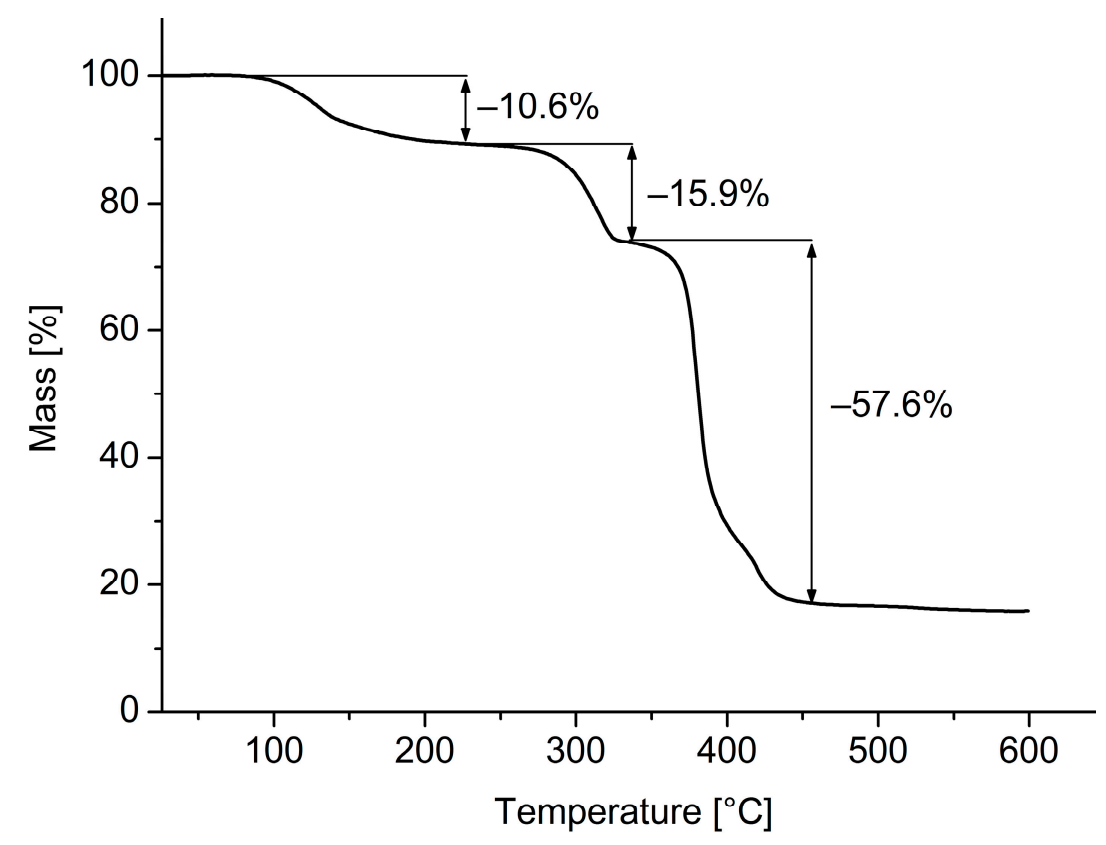

Figure 6. TGA curve of $[\mathrm{Zn}(1,3-\mathrm{BDC}) \mathrm{Dptztz}] \cdot \mathrm{DMF} \cdot$ in the temperature range $26-600{ }^{\circ} \mathrm{C}$ with a heating rate of $10 \mathrm{~K} / \mathrm{min}$ under $\mathrm{N}_{2}$ atmosphere.

Prior to the sorption experiments the crystals of [Zn(1,3-BDC)Dptztz].DMF were collected by suction filtration. Afterwards they were suspended in acetonitrile for three days to induce solvent exchange as part of the sample activation procedure. Additionally, the acetonitrile solvent was exchanged three times per day. Afterwards, the sample was degassed at $120^{\circ} \mathrm{C}$ for $15 \mathrm{~h}$ under vacuum. 
The activated compound [ $\mathrm{Zn}(1,3-\mathrm{BDC})$ Dptztz] shows no uptake of $\mathrm{N}_{2}$ at $77 \mathrm{~K}$, which is in accordance with the observations by Kitagawa et al. for analogous CID structures [24-29]. For $\mathrm{CO}_{2}$-with its large polarizability and quadrupole moment-[Zn(1,3-BDC)Dptztz] shows a type I adsorption isotherm at $195 \mathrm{~K}$ with a maximum uptake of $138 \mathrm{~cm}^{3} / \mathrm{g}$ at $753 \mathrm{mmHg}$ of $\mathrm{CO}_{2}$ (Figure 7). At higher absolutes pressures the desorption curve shows a small hysteresis, but at low pressures the hysteresis gap closes. This proves the microporous nature of [Zn(1,3-BDC)Dptztz]. Because [ $\mathrm{Zn}(1,3-\mathrm{BDC}) \mathrm{Dptztz}]$ is non-porous towards $\mathrm{N}_{2}$ the $\mathrm{CO}_{2}$ data was used to calculated the BET surface area. The BET surface area from the $\mathrm{CO}_{2}$ adsorption isotherm is $417 \mathrm{~m}^{2} / \mathrm{g}$ (calculated from $\mathrm{p} / \mathrm{p}_{0}=0.00-0.04$ ). The pore volume is $0.246 \mathrm{~cm}^{3} / \mathrm{g}$ at $\mathrm{p} / \mathrm{p}_{0}=0.5$ calculated from the isotherm measured at $195 \mathrm{~K}$. The calculated accessible surface area is $25.6 \%$ or $0.185 \mathrm{~cm}^{3} / \mathrm{g}$ calculated with PLATON from the DMF solvent-depleted structure. The measured pore volume is about $35 \%$ higher than the one calculated from the crystal structure data. This can be interpreted such that $\mathrm{CO}_{2}$ can create a larger interlayer volume through strong interaction with the highly polarized surface area at $195 \mathrm{~K}$.

Additionally, the $\mathrm{CO}_{2}$ isotherms at $273 \mathrm{~K}$ and $293 \mathrm{~K}$ were measured (Figure 7). The data is presented in Table 3. From the $\mathrm{CO}_{2}$ isotherms at $273 \mathrm{~K}$ and $293 \mathrm{~K}$, the heat of adsorption at zero coverage was derived as $26.2 \mathrm{~kJ} / \mathrm{mol}$. The heat of adsorption of $\mathrm{CO}_{2}$ for MOFs can vary from $20 \mathrm{~kJ} / \mathrm{mol}$ to over $90 \mathrm{~kJ} / \mathrm{mol}$. A higher heat of adsorption is usually indicative for stronger framework $\mathrm{CO}_{2}$ interactions [47]. Representative values are 20kJ/mol for [Zn(1,4-BDC)(TED)], $30 \mathrm{~kJ} / \mathrm{mol}$ for HKUST-1, $47 \mathrm{~kJ} / \mathrm{mol}$ for Mg-MOF-74, $63 \mathrm{~kJ} / \mathrm{mol}$ for MIL-100-Cr and $96 \mathrm{~kJ} / \mathrm{mol}$ for mmen-Cu-BTTri [48-52].

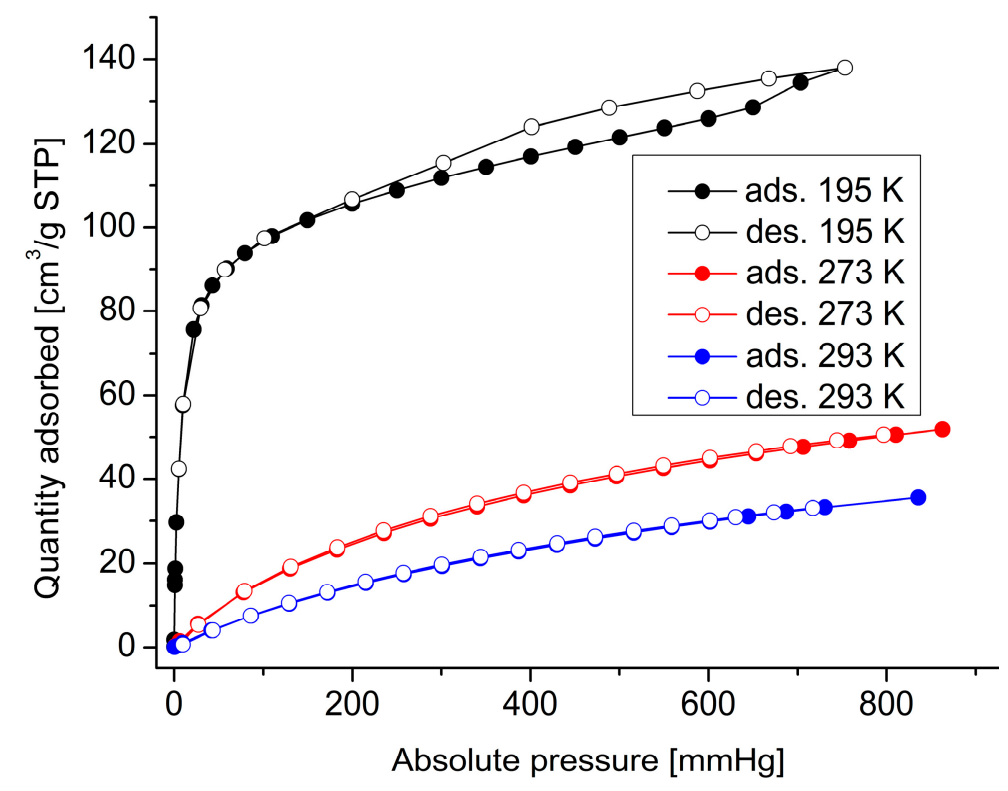

Figure 7. $\mathrm{CO}_{2}$ adsorption (closed symbols) and desorption (open symbols) isotherms for activated [Zn(1,3-BDC)Dptztz] measured at $195 \mathrm{~K}$ (black), $293 \mathrm{~K}$ (red) and $273 \mathrm{~K}$ (blue).

Table 3. $\mathrm{CO}_{2}$ sorption data for $[\mathrm{Zn}(1,3-\mathrm{BDC}) \mathrm{Dptztz}]$.

\begin{tabular}{ccc}
\hline & $\begin{array}{c}\text { Quantity Adsorbed } \\
\left(\mathbf{c m}^{\mathbf{3}} / \mathbf{g}, \mathbf{m m o l} / \mathbf{g}, \mathbf{w t} \mathbf{\%}\right)\end{array}$ & Total Pore Volume $\mathbf{( \mathbf { c m } ^ { 3 } / \mathbf { g } )}$ \\
\hline $195 \mathrm{~K}$ & $138,6.16,27.1 \%$ & $0.2466^{1}$ \\
$273 \mathrm{~K}$ & $51.9,2.32,10.2 \%$ & $0.092^{2}$ \\
$293 \mathrm{~K}$ & $35.5,1.59,7.0 \%$ & $0.061^{3}$ \\
\hline & ${ }^{1}$ at $\mathrm{p} / \mathrm{p}_{0}=0.50,{ }^{2}$ at $\mathrm{p} / \mathrm{p}_{0}=0.03,{ }^{3}$ at $\mathrm{p} / \mathrm{p}_{0}=0.017$.
\end{tabular}


The heat of adsorption curve (Figure 8) has a relative maximum at a quantity adsorbed of about $4 \mathrm{~cm}^{3} / \mathrm{g} \mathrm{STP}$ with $27.7 \mathrm{~kJ} / \mathrm{mol}$. Afterwards the heat of adsorption decreases to $25.7 \mathrm{~kJ} / \mathrm{mol}$. For most MOF materials, the heat of adsorption curve decreases monotonically, since the adsorption sites with the highest affinity towards the adsorbate are occupied first and at higher loadings the adsorption sites usually have weaker affinities. Two MOF classes for which the heat of adsorption does not decrease monotonically are the MIL-53 and MIL-47 series. Férey et al. suggested that the transformation of MIL-53 from a closed or narrow-pore to the open or wide-pore phase is an endothermic process and that this process is balanced with the exothermic adsorption process. Subsequently, the MIL-53 MOFs also have a local maximum between 0 and 1 bar (see Figure S4 in Supplementary Material) [53]. Many CIDs also show gate-opening phenomena and/or an adsorbate specific expansion upon the adsorption process. Yet, to the best of our knowledge, no heat of adsorption curves for CIDs are published in the literature. But Pera-Titus and Farruseng calculated the phase transition energies for CID-21 and CID-22 (benzene and tetrazine spacer) to be 1.4 and $1.5 \mathrm{~kJ} / \mathrm{mol}$ from the closed to the open phase for $\mathrm{CO}_{2}$ adsorption at $195 \mathrm{~K}$, respectively [54]. These values are in good accordance with the difference between the heat of adsorption at zero coverage and the relative maximum of the curve in Figure 8. So it can be concluded that $[\mathrm{Zn}(1,3-\mathrm{BDC}) \mathrm{Dptztz}]$ shows a gate-opening effect for $\mathrm{CO}_{2}$, which is represented in a non-monotonic heat of adsorption curve.

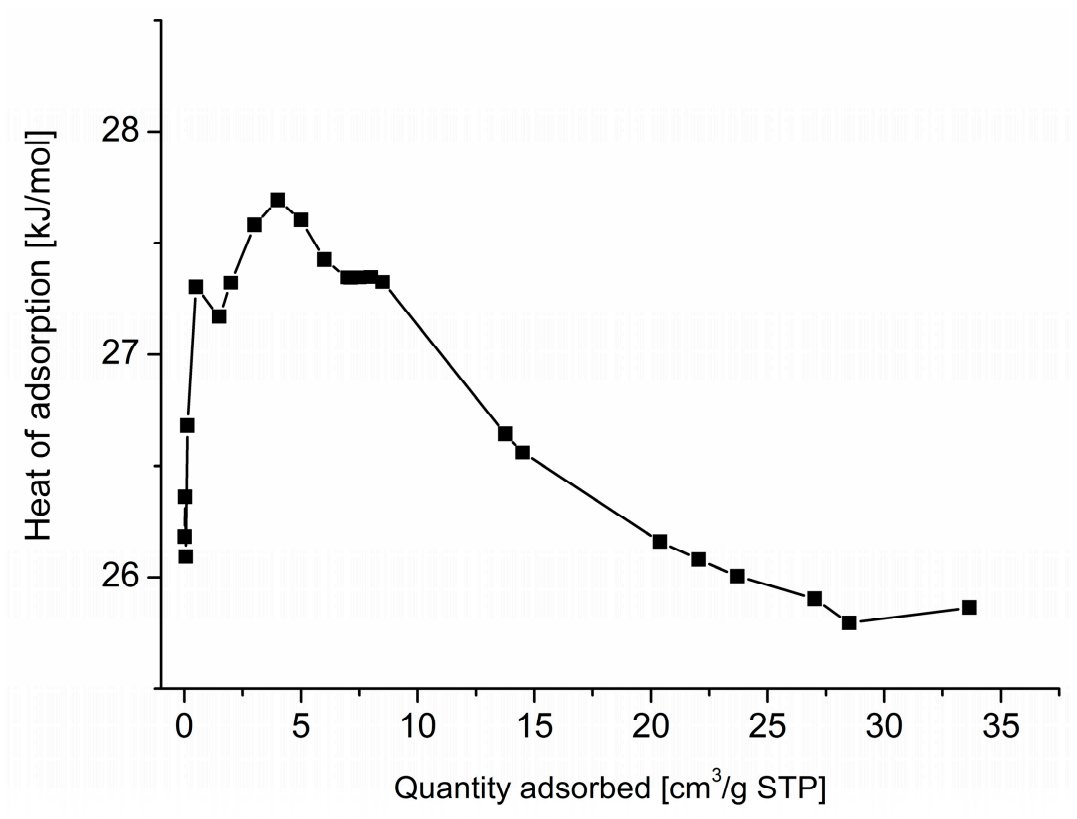

Figure 8. Heat of adsorption plot of $\mathrm{CO}_{2}$ adsorption for [Zn(1,3-BDC)Dptztz].

Compound [Zn(1,3-BDC)Dptztz] gradually adsorbs $\mathrm{H}_{2} \mathrm{O}$ at $293 \mathrm{~K}$ with a maximum uptake of $121 \mathrm{mg} / \mathrm{g}$ at $0.9 \mathrm{p} / \mathrm{p}_{0}$ (Figure 9). This uptake equals $3.5 \mathrm{H}_{2} \mathrm{O}$ molecules per asymmetric unit. The desorption curve shows a hysteresis, indicative for a strong interaction of $\mathrm{H}_{2} \mathrm{O}$ with the framework. [Zn(1,3-BDC)Dptztz] adsorbs $\mathrm{CO}_{2}$ at $195 \mathrm{~K}$ due to its large polarizability and quadrupole moment while $\mathrm{N}_{2}$ at $77 \mathrm{~K}$ is not adsorbed. The adsorption characteristics of [Zn(1,3-BDC)Dptztz] apparently depend on the interaction between the adsorbate and the framework und not only on the pore size. The sorption characteristics of [ $\mathrm{Zn}(1,3-\mathrm{BDC})$ Dptztz] towards $\mathrm{H}_{2} \mathrm{O}$ with its pronounced hysteresis underpin these findings. It can be concluded that the decoration of the surface with the polarized and electron poor tztz moiety can alter sorption properties to become highly selective towards polarizable adsorbents. Further studies on different tztz-containing materials are underway in our institute. 


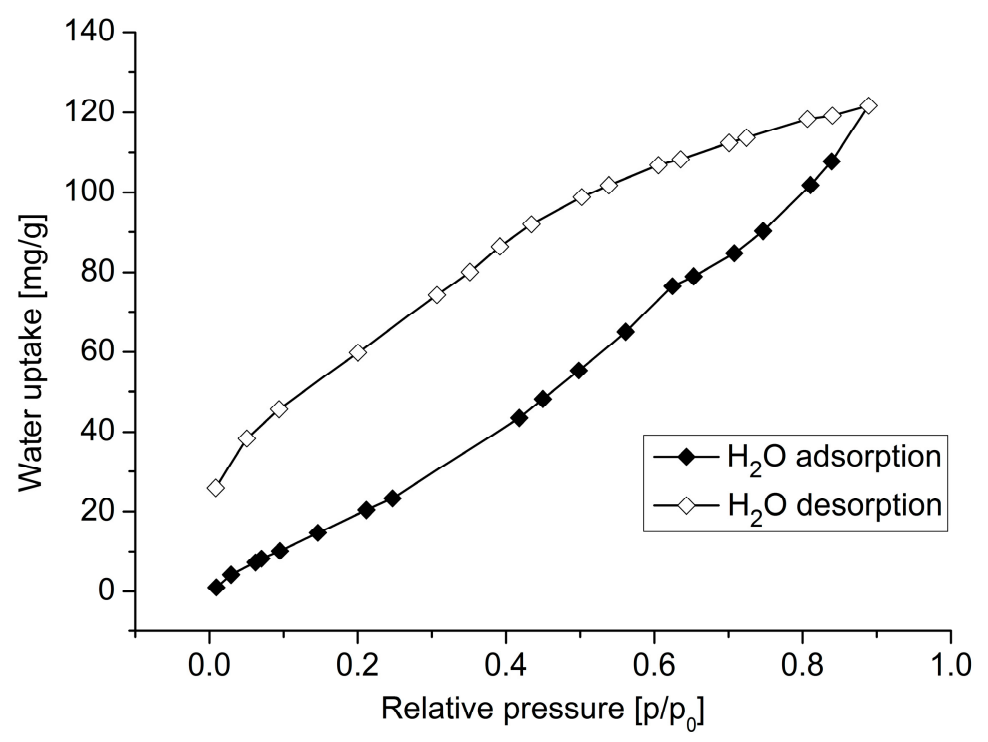

Figure 9. Water sorption isotherms at $293 \mathrm{~K}$ for [Zn(1,3-BDC)Dptztz].

\section{Conclusions}

The 4,4'-dipyridyl $N, N^{\prime}$-donor ligand Dptztz with the central thiazolo[5,4-d]thiazole unit was successfully synthesized and its crystal structure was determined for the first time. With the linker Dptztz, the thiazolo[5,4-d]thiazole-unit was integrated into a solvent-filled coordination network of the formula [Zn(1,3-BDC)Dptztz].DMF belonging to the class of coordination polymers with interdigitated structure (CIDs). Synthesis of the coordination network was carried out via a mixed ligand strategy in a solvothermal reaction. Interdigitation between the 2D layers to a 3D supramolecular network appears to be controlled by $\pi-\pi$ interactions between isophthalate aryl rings and $\mathrm{CH}-\pi$ interactions between isophthalate and pyridyl moieties. Activated [Zn(1,3-BDC)Dptztz] shows a BET surface of $417 \mathrm{~m}^{2} / \mathrm{g}$ calculated from $\mathrm{CO}_{2}$ adsorption data, while $\mathrm{N}_{2}$ which unlike $\mathrm{CO}_{2}$ is not as polarizable and has no quadrupole moment is not adsorbed. The heat of adsorption for $\mathrm{CO}_{2}$ exhibits a relative maximum at a quantity adsorbed of about $4 \mathrm{~cm}^{3} / \mathrm{g}$ STP with $27.7 \mathrm{~kJ} / \mathrm{mol}$, which is interpreted as a gate-opening effect. This is the first report of the sorption characteristics of a tztz-functionalized porous MOF material.

Supplementary Materials: The following are available online at www.mdpi.com/2073-4352/8/1/30/s1. Figure S1: Section of the packing diagram of 2,5-di(4-pyridyl)thiazolo[5,4-d]thiazole (Dptztz), showing (a) the complementary $\mathrm{C} 1-\mathrm{H} 1 \cdots \mathrm{N} 1$ hydrogen bonds and (b) the $\pi-\pi$ interactions, thereby giving a supramolecular layer in the $a b$ plane; Figure S2: Asymmetric unit of [Zn(1,3-BDC)Dptztz].DMF showing the ring-flip disorder of the thiazolothiazol moiety; Figure S3: $\pi-\pi$ and $\mathrm{CH}-\pi$ interactions between the 2D layers in [ $\mathrm{Zn}(1,3-\mathrm{BDC}) \mathrm{Dptztz}$; Figure S4: Heat of adsorption curve of MIL-53-Cr; Table S1. Distances [ $[\AA]$ and angles $\left[{ }^{\circ}\right]$ for the shortest $\pi-\pi$ and $\mathrm{CH}-\pi$ supramolecular interactions between the $2 \mathrm{D}$ layers in [Zn(1,3-BDC)Dptztz].

Acknowledgments: The work was supported by the Federal German Ministry of Education and Research (BMBF) under grant-\# 03SF0492C (Optimat).

Author Contributions: Simon Millan designed the experiments, synthesized the ligand and [ $\mathrm{Zn}(1,3-\mathrm{BDC}) \mathrm{Dptztz}]$. Gamall Makhloufi collected the single crystal data. Data analysis and measurements were performed by Simon Millan, while Christoph Janiak and Simon Millan wrote the manuscript.

Conflicts of Interest: The authors declare no conflict of interest. The founding sponsors had no role in the design of the study; in the collection, analyses, or interpretation of data; in the writing of the manuscript, and in the decision to publish the results.

\section{References}

1. Yaghi, O.M.; O’Keeffe, M.; Ockwig, N.W.; Chae, H.K.; Eddaoudi, M.; Kim, J. Reticular synthesis and the design of new materials. Nature 2003, 423, 705-714. [CrossRef] [PubMed] 
2. Maurin, G.; Serre, C.; Cooper, A.; Férey, G. The new age of MOFs and of their porous-related solids. Chem. Soc. Rev. 2017, 46, 3104-3107. [CrossRef] [PubMed]

3. Furukawa, H.; Ko, N.; Go, Y.B.; Aratani, N.; Choi, S.B.; Choi, E.; Yazaydin, A.Ö.; Snurr, R.Q.; O’Keeffe, M.; Kim, J.; Yaghi, O.M. Ultrahigh porosity in metal-organic frameworks. Science 2010, 329, 424-428. [CrossRef] [PubMed]

4. Adil, K.; Belmabkhout, Y.; Pillai, R.S.; Cadiau, A.; Bhatt, P.M.; Assen, A.H.; Maurin, G.; Eddaoudi, M. Gas/vapour separation using ultra-microporous metal-organic frameworks: Insights into the structure/separation relationship. Chem. Soc. Rev. 2017, 46, 3402-3430. [CrossRef] [PubMed]

5. Li, J.-R.; Kuppler, R.J.; Zhou, H.-C. Selective gas adsorption and separation in metal-organic frameworks. Chem. Soc. Rev. 2009, 38, 1477-1504. [CrossRef] [PubMed]

6. Dechnik, J.; Gascon, J.; Doonan, C.J.; Janiak, C.; Sumby, C.J. Mixed-matrix membranes. Angew. Chem. Int. Ed. 2017, 56, 9292-9310. [CrossRef] [PubMed]

7. Lee, J.; Farha, O.K.; Roberts, J.; Scheidt, K.A.; Nguyen, S.T.; Hupp, J.T. Metal-organic framework materials as catalysts. Chem. Soc. Rev. 2009, 38, 1450-1459. [CrossRef] [PubMed]

8. Herbst, A.; Janiak, C. MOF catalysts in biomass upgrading towards value-added fine chemicals. CrystEngComm 2017, 19, 4092-4117. [CrossRef]

9. Kitao, T.; Zhang, Y.; Kitagawa, S.; Wang, B.; Uemura, T. Hybridization of MOFs and polymers. Chem. Soc. Rev. 2017, 46, 3108-3133. [CrossRef] [PubMed]

10. Lustig, W.P.; Mukherjee, S.; Rudd, N.D.; Desai, A.V.; Li, J.; Ghosh, S.K. Metal-organic frameworks: functional luminescent and photonic materials for sensing applications. Chem. Soc. Rev. 2017, 46, 3242-3285. [CrossRef] [PubMed]

11. Hu, Z.; Deibert, B.J.; Li, J. Luminescent metal-organic frameworks for chemical sensing and explosive detection. Chem. Soc. Rev. 2014, 43, 5815-5840. [CrossRef] [PubMed]

12. Gangu, K.K.; Maddila, S.; Mukkamala, S.B.; Jonnalagadda, S.B. A review on contemporary Metal-Organic Framework materials. Inorg. Chim. Acta 2016, 446, 61-74. [CrossRef]

13. Jeremias, F.; Fröhlich, D.; Janiak, C.; Henninger, S.K. Water and methanol adsorption on MOFs for cycling heat transformation processes. New J. Chem. 2014, 38, 1846-1852. [CrossRef]

14. Almeida Paz, F.A.; Klinowski, J.; Vilela, S.M.F.; Tome, J.P.C.; Cavaleiro, J.A.S.; Rocha, J. Ligand design for functional metal-organic frameworks. Chem. Soc. Rev. 2012, 41, 1088-1110. [CrossRef] [PubMed]

15. Tanabe, K.K.; Cohen, S.M. Postsynthetic modification of metal-organic frameworks-A progress report. Chem. Soc. Rev. 2011, 40, 498-519. [CrossRef] [PubMed]

16. Islamoglu, T.; Goswami, S.; Li, Z.; Howarth, A.J.; Farha, O.K.; Hupp, J.T. Postsynthetic tuning of metal-organic frameworks for targeted applications. Acc. Chem. Res. 2017, 50, 805-813. [CrossRef] [PubMed]

17. Biradha, K.; Sarkar, M.; Rajput, L. Crystal engineering of coordination polymers using $4,4^{\prime}$-bipyridine as a bond between transition metal atoms. Chem. Commun. 2006, 4169-4179. [CrossRef] [PubMed]

18. Bhattacharya, B.; Ghoshal, D. Selective carbon dioxide adsorption by mixed-ligand porous coordination polymers. CrystEngComm 2015, 17, 8388-8413. [CrossRef]

19. Haldar, R.; Maji, T.K. Metal-organic frameworks (MOFs) based on mixed linker systems: Structural diversities towards functional materials. CrystEngComm 2013, 15, 9276-9295. [CrossRef]

20. Bae, Y.-S.; Mulfort, K.L.; Frost, H.; Ryan, P.; Punnathanam, S.; Broadbelt, L.J.; Hupp, J.T.; Snurr, R.Q. Separation of $\mathrm{CO}_{2}$ from $\mathrm{CH}_{4}$ using mixed-ligand metal-organic frameworks. Langmuir 2008, 24, 8592-8598. [CrossRef] [PubMed]

21. Henke, S.; Schneemann, A.; Wütscher, A.; Fischer, R.A. Directing the breathing behavior of pillared-layered metal-organic frameworks via a systematic library of functionalized linkers bearing flexible substituents. J. Am. Chem. Soc. 2012, 134, 9464-9474. [CrossRef] [PubMed]

22. Glomb, S.; Woschko, D.; Makhloufi, G.; Janiak, C. Metal-organic frameworks with internal urea-functionalized dicarboxylate linkers for $\mathrm{SO}_{2}$ and $\mathrm{NH}_{3}$ adsorption. ACS Appl. Mater. Interfaces 2017, 9, 37419-37434. [CrossRef] [PubMed]

23. Takashima, Y.; Martínez, V.M.; Furukawa, S.; Kondo, M.; Shimomura, S.; Uehara, H.; Nakahama, M.; Sugimoto, K.; Kitagawa, S. Molecular decoding using luminescence from an entangled porous framework. Nat. Commun. 2011, 2, 168. [CrossRef] [PubMed] 
24. Horike, S.; Tanaka, D.; Nakagawa, K.; Kitagawa, S. Selective guest sorption in an interdigitated porous framework with hydrophobic pore surfaces. Chem. Commun. 2007, 3395-3397. [CrossRef]

25. Tanaka, D.; Nakagawa, K.; Higuchi, M.; Horike, S.; Kubota, Y.; Kobayashi, T.C.; Takata, M.; Kitagawa, S. Kinetic gate-opening process in a flexible porous coordination polymer. Angew. Chem. Int. Ed. 2008, 47, 3914-3918. [CrossRef] [PubMed]

26. Fukushima, T.; Horike, S.; Inubushi, Y.; Nakagawa, K.; Kubota, Y.; Takata, M.; Kitagawa, S. Solid solutions of soft porous coordination polymers: Fine-tuning of gas adsorption properties. Angew. Chem. 2010, 122, 4930-4934. [CrossRef]

27. Nakagawa, K.; Tanaka, D.; Horike, S.; Shimomura, S.; Higuchi, M.; Kitagawa, S. Enhanced selectivity of $\mathrm{CO}_{2}$ from a ternary gas mixture in an interdigitated porous framework. Chem. Commun. 2010, 46, 4258-4260. [CrossRef] [PubMed]

28. Hijikata, Y.; Horike, S.; Sugimoto, M.; Sato, H.; Matsuda, R.; Kitagawa, S. Relationship between channel and sorption properties in coordination polymers with interdigitated structures. Chem. Eur. J. 2011, 17, 5138-5144. [CrossRef] [PubMed]

29. Kishida, K.; Horike, S.; Nakagawa, K.; Kitagawa, S. Synthesis and adsorption properties of azulene-containing porous interdigitated framework. Chem. Lett. 2012, 41, 425-426. [CrossRef]

30. Johnson, J.R.; Ketcham, R. Thiazolothiazoles. I. The reaction of aromatic aldehydes with dithiooxamide. J. Am. Chem. Soc. 1960, 82, 2719-2724. [CrossRef]

31. Bevk, D.; Marin, L.; Lutsen, L.; Vanderzande, D.; Maes, W. Thiazolo[5,4-d]thiazoles - promising building blocks in the synthesis of semiconductors for plastic electronics. RSC Adv. 2013, 3, 11418-11431. [CrossRef]

32. Reginato, G.; Mordini, A.; Zani, L.; Calamante, M.; Dessi, A. Photoactive compounds based on the thiazolo[5,4-d]thiazole core and their application in organic and hybrid photovoltaics. Eur. J. Org. Chem. 2016, 233-251. [CrossRef]

33. Zampese, J.A.; Keene, F.R.; Steel, P.J. Diastereoisomeric dinuclear ruthenium complexes of 2,5-di(2-pyridyl)thiazolo[5,4-d]thiazole. Dalton Trans. 2004, 4124-4129. [CrossRef] [PubMed]

34. Falcão, E.H.L.; Naraso; Feller, R.K.; Wu, G.; Wudl, F.; Cheetham, A.K. Hybrid organic-inorganic framework structures: Influence of cation size on metal-oxygen-metal connectivity in the alkaline earth thiazolothiazoledicarboxylates. Inorg. Chem. 2008, 47, 8336-8342.

35. Aprea, A.; Colombo, V.; Galli, S.; Masciocchi, N.; Maspero, A.; Palmisano, G. Thiazolo[5,4-d]thiazole-2,5dicarboxylic acid, $\mathrm{C}_{6} \mathrm{H}_{2} \mathrm{~N}_{2} \mathrm{O}_{4} \mathrm{~S}_{2}$, and its coordination polymers. Solid State Sci. 2010, 12, 795-802. [CrossRef]

36. Rizzuto, F.J.; Faust, T.B.; Chan, B.; Hua, C.; D’Alessandro, D.M.; Kepert, C.J. Experimental and computational studies of a multi-electron donor-acceptor ligand containing the thiazolo[5,4-d]thiazole core and its incorporation into a metal-organic framework. Chem. Eur. J. 2014, 20, 17597-17605. [CrossRef] [PubMed]

37. Hua, C.; Rizzuto, F.J.; Zhang, X.; Tuna, F.; Collison, D.; D'Alessandro, D.M. Spectroelectrochemical properties of a $\mathrm{Ru}(\mathrm{II})$ complex with a thiazolo[5,4-d]thiazole triarylamine ligand. New J. Chem. 2017, 41, 108-114. [CrossRef]

38. Zhu, X.; Tian, C.; Jin, T.; Wang, J.; Mahurin, S.M.; Mei, W.; Xiong, Y.; Hu, J.; Feng, X.; Liu, H. Thiazolothiazole-linked porous organic polymers. Chem. Commun. 2014, 50, 15055-15058. [CrossRef] [PubMed]

39. APEX2. SAINT, Data Reduction and Frame Integration Program for the CCD Area-Detector System, Bruker Analytical X-ray Systems; Data Collection Program for the CCD Area-Detector System: Madison, WI, USA, 1997-2006.

40. Sheldrick, G.M. SADABS: Area-Detector Absorption Correction; University of Göttingen: Göttingen, Germany, 1996.

41. Sheldrick, G.M. Crystal structure refinement with SHElXL. Acta Crystallogr. Sect A 2015, 71, 3-8. [CrossRef] [PubMed]

42. Sheldrick, G. A short history of SHELX. Acta Crystallogr. Sect. A 2008, 64, 112-122. [CrossRef] [PubMed]

43. Brandenburg, K. DIAMOND, version 4.4; Crystal and Molecular Structure Visualization; Crystal Impact-K. Brandenburg \& H. Putz Gbr: Bonn, Germany, 2009-2017.

44. Spek, A.L. Structure validation in chemical crystallography. Acta Crystallogr. Sect. D—Biol. Crystallogr. 2009, 65, 148-155. [CrossRef] [PubMed]

45. Knighton, R.C.; Hallett, A.J.; Kariuki, B.M.; Pope, S.J.A. A one-step synthesis towards new ligands based on aryl-functionalised thiazolo[5,4-d]thiazole chromophores. Tetrahedron Lett. 2010, 51, 5419-5422. [CrossRef] 
46. Hisamatsu, S.; Masu, H.; Azumaya, I.; Takahashi, M.; Kishikawa, K.; Kohmoto, S. U-shaped aromatic ureadicarboxylic acids as versatile building blocks: Construction of ladder and zigzag networks and channels. Cryst. Growth Des. 2011, 11, 5387-5395. [CrossRef]

47. Das, A.; D'Alessandro, D.M. Tuning the functional sites in metal-organic frameworks to modulate $\mathrm{CO}_{2}$ heats of adsorption. CrystEngComm 2015, 17, 706-718. [CrossRef]

48. Zhao, Y.; Wu, H.; Emge, T.J.; Gong, Q.; Nijem, N.; Chabal, Y.J.; Kong, L.; Langreth, D.C.; Liu, H.; Zeng, H.; $\mathrm{Li}$, J. Enhancing gas adsorption and separation capacity through ligand functionalization of microporous metal-organic framework structures. Chem. Eur. J. 2011, 17, 5101-5109. [CrossRef] [PubMed]

49. Liang, Z.; Marshall, M.; Chaffee, A.L. $\mathrm{CO}_{2}$ adsorption-based separation by metal organic framework (Cu-BTC) versus zeolite (13X). Energy Fuels 2009, 23, 2785-2789. [CrossRef]

50. Caskey, S.R.; Wong-Foy, A.G.; Matzger, A.J. Dramatic tuning of carbon dioxide uptake via metal substitution in a coordination polymer with cylindrical pores. J. Am. Chem. Soc. 2008, 130, 10870-10871. [CrossRef] [PubMed]

51. Llewellyn, P.L.; Bourrelly, S.; Serre, C.; Vimont, A.; Daturi, M.; Hamon, L.; De Weireld, G.; Chang, J.-S.; Hong, D.-Y.; Kyu Hwang, Y.; et al. High uptakes of $\mathrm{CO}_{2}$ and $\mathrm{CH}_{4}$ in mesoporous metal-organic frameworks MIL-100 and MIL-101. Langmuir 2008, 24, 7245-7250. [CrossRef] [PubMed]

52. McDonald, T.M.; D'Alessandro, D.M.; Krishna, R.; Long, J.R. Enhanced carbon dioxide capture upon incorporation of $N, N^{\prime}$-dimethylethylenediamine in the metal-organic framework CuBTTri. Chem. Sci. 2011, 2, 2022-2028. [CrossRef]

53. Bourrelly, S.; Llewellyn, P.L.; Serre, C.; Millange, F.; Loiseau, T.; Férey, G. Different adsorption behaviors of methane and carbon dioxide in the isotypic nanoporous metal terephthalates MIL-53 and MIL-47. J. Am. Chem. Soc. 2005, 127, 13519-13521. [CrossRef] [PubMed]

54. Pera-Titus, M.; Farrusseng, D. Guest-induced gate opening and breathing phenomena in soft porous crystals: Building thermodynamically consistent isotherms. J. Phys. Chem. C 2012, 116, 1638-1649. [CrossRef]

(c) 2018 by the authors. Licensee MDPI, Basel, Switzerland. This article is an open access article distributed under the terms and conditions of the Creative Commons Attribution (CC BY) license (http:/ / creativecommons.org/licenses/by/4.0/). 